\title{
Investigating university students' attitudes towards infertility in terms of socio-demographic variables
}

\begin{abstract}
BACKGROUND
Despite the development of medical interventions, being infertile is still deemed a shameful and humiliating experience and perceived as a failure. The aim of the study was to investigate university students' attitudes towards infertility in terms of socio-demographic variables and risky behaviors in Turkey.
\end{abstract}

\section{PARTICIPANTS AND PROCEDURE}

It was a cross-sectional study with a self-administered scale. A total of 9693 university students $(5002$ female, 4691 male) from 12 statistical regions of Turkey participated in the study.

\section{RESULTS}

According to the findings of the study, $26.99 \%$ of the Turkish university students believed that lives of couples without a child are incomplete, $49.00 \%$ stated that they would not marry again if their partner was infertile, and $70.05 \%$ did not agree that women who do not have a child are faulty. Like the limited studies done before, male students reported more negative attitudes towards infertility than female students. Students who received sexual health education and knew someone infertile in their social network had more positive attitudes.

\section{CONCLUSIONS}

The results of the study indicated that university students' attitudes towards infertility are relatively positive. Gender differences in attitudes towards infertility indicate that psycho-education programs about infertility including gender role issues can be developed and applied for Turkish university students.

\section{KEY WORDS}

infertility; attitudes; university students; prevention

ORganization - 1: Department of Counseling and Guidance, Dokuz Eylul University, Izmir, Turkey · 2: Manisa Celal Bayar University, Manisa, Turkey · 3: Department of Counseling and Guidance, Ege University, Izmir, Turkey . 4: Urology Clinic, Buca Seyfi Demirsoy State Hospital, Izmir, Turkey · : Department of Computer Education and Instructional Technology, Dokuz Eylul University, Izmir, Turkey

authors' Contributions - A: Study design - B: Data collection - C: Statistical analysis - D: Data interpretation .

E: Manuscript preparation · F: Literature search · G: Funds collection

Corresponding Author - Erol Esen, Ph.D., Faculty of Education, Manisa Celal Bayar University, Demirci, 45190 Manisa, Turkey, e-mail: midfielder_1912@hotmail.com

to Cite this ARtıcle - Siyez, D. M., Seymenler, S., Kağnıcı, Y., Esen, E., Siyez, E., \& Baran, B. (2018). Investigating university students' attitudes towards infertility in terms of socio-demographic variables. Health Psychology Report, 6(4), 351-360. https://doi.org/10.5114/hpr.2018.77181 


\section{BACKGROUND}

Having a child is accepted as a psychological, biological, social and cultural need for almost every community. Due to strong cultural expectations, couples think about how many children they want and when they want them instead of considering whether they will be able to have a child or not. Although it varies from country to country around the world, almost 50 million people are expected to face the reality that
Diğdem Müge Siyez,

Seçil Seymenler, Yelda Kağnıcı,

Erol Esen,

Ender Siyez,

Bahar Baran they may not meet this main marriage expectation. Infertility is a disease characterized by the failure to establish a clinical pregnancy after 12 months of regular, unprotected sexual intercourse or due to an impairment of a person's capacity to reproduce either as an individual or with his/her partner (ZegersHochschild et al., 2017).

Infertility is considered a life crisis, since it may have important and serious effects on couples (Gibson, 2007). Studies on infertility show that infertility needs to be considered as a bio-psychosocial crisis since it includes not only biological factors and medical interventions but also personal and psychological characteristics, cultural assumptions regarding parenting, and social networks' reactions (Van den Broeck, Emery, Wischmann, \& Thorn, 2010). As a result of infertility, couples face many psychological, physical, economic and emotional burdens (Gibson, 2007).

Being shocked and surprised are the first reactions of individuals diagnosed with infertility. After many unsuccessful attempts at fertility treatment, infertile individuals' emotions become more afflictive (Burns, 2005). Infertile individuals experience loss not only about rearing a child but also in many aspects of their lives as a goal of life, pregnancy experience, reproduction ability, personal identity and sexual identity (Harris \& Daniluk, 2010). These multiple losses cause many complex feelings such as grief, anxiety, loneliness, fear, sadness, anger, inferiority, shame, desperation, moodiness, weakness, betrayal and low self-esteem (Gibson, 2007).

Despite the development of medical interventions and social relationships, being infertile is still defined as a shameful and humiliating experience and perceived as a failure. In many societies being parents is at the center of cultural and social gender norms. Being unable to have a child is perceived as an incompetency and causes social pressure on couples. Negative attitudes and perceptions towards infertility can be observed in various forms. Stigmatization and divorce are the most negative results of these attitudes and perceptions (Ramezanzadeh et al., 2004). Besides trying to meet this social expectation, couples also deal with stigmas (Slade, O’Neill, Simpson, \& Lashen, 2007). Infertile couples and individuals commonly report that they feel stigmatized and perceive negative attitudes from others (Lampman \& Dowling-Guyer,
1995). Stigmatization increases when people feel that they cannot function within the social norms although they want to. Infertile women and men experience disreputability both in society and among themselves since they are perceived as people who deviate from the normal flow of life (Sewall \& Burns, 2006). Couples without a child can be perceived as immature, selfish, unhappy and career-oriented individuals (Gibson, 2007). Such biases cause isolation of infertile individuals (Burns, 2005) and result in loss of close relationships with the social network and family members (Harris \& Daniluk, 2010).

When the literature is reviewed, it is seen that attitudes towards infertility have been examined with studies about attitudes towards having child (Peterson, Pirritano, Tucker, \& Lampic, 2012; Sørensen et al., 2016) and attitudes of infertile couples (Abolfotouh, Alabdrabalnabi, Albacker, Al-Jughaiman, \& Hassan, 2013; Gerhard, Ritenour, Goodman, Vashi, \& Hsiao, 2014; Yazdani, Kazemi, \& Ureizi-Samani, 2016). One of the risk factors for infertility is postponing plans for having a child without the awareness that age is critical in reproduction. Postponing child plans is generally related to academic and career goals. University students consider postponing child plans in order to achieve these goals (Meissner, Schippert, \& Von Versen-Höynck, 2016). There are not enough studies about university students' attitudes towards infertility and related factors. It is believed that examining university students' attitudes towards infertility is very important in Turkey, since $16.38 \%$ of the population in Turkey is aged between 14 and 24 (Turkish Statistical Institute, 2016a). However, there are only two studies (Güngör, Rathfisch, Kızılkaya Beji, Yarar, \& Karamanoğlu, 2013; Taşcı \& Özkan, 2007) about university students' views and beliefs regarding infertility in Turkey. According to the results of these studies, males and individuals who want to have a child have more negative attitudes towards infertility and females are more concerned about being infertile.

Considering the factors that cause infertility, it is seen that some factors have preventable characteristics. Tuberous obstruction due to untreated pelvic inflammatory disease and undiagnosed sexually transmitted diseases are examples of such cases (Trent, Millstein, \& Ellen, 2006). At the same time, smoking cigarettes, drinking alcohol and caffeine regularly, and having low (underweight) or high body mass index (overweight) are considered as risk factors for infertility (Bunting \& Boivin, 2007; Pasquali, Patton, \& Gambineri, 2007; Schmid, Kirchengast, VytiskaBinstorfer, \& Huber, 2004; Wyndham, Marin Figueira, \& Patrizio, 2012).

In the shaping of attitudes, individuals' past experiences are influential. When examining the attitudes towards infertility, it is wondered how having the risk factors will influence the attitudes. In this context, the present study has two research questions: What are 
the university students' attitudes towards infertility? Is there a significant difference in university students' attitudes towards infertility in terms of socio-demographic variables (gender, age, receiving sexual health education, having a sexual relationship, having infertile individuals in the social network, having plans about having a child) and risky behaviors (smoking cigarettes, drinking alcohol and caffeine excessively, having low or high body mass index)?

\section{PARTICIPANTS AND PROCEDURE}

\section{PARTICIPANTS}

The study population consisted of university students attending state universities in Turkey. In order to determine the sample, Statistical Regional Units Classification (NUTS) was used. According to this classification, there are 12 statistical regions in Turkey (Istanbul, West Anatolia, East Marmara, Ege, West Marmara, Mediterranean, West Black Sea, Anatolia, East Black Sea, Southeastern Anatolia, Middle East Anatolia and Northeastern Anatolia). Since some of these regions do not have private universities, private universities were not included in the study.

In order to determine the sample, a number of students were obtained in these regions' state universities. Universities were randomly selected from each region. According to the Higher Education Council, the number of students in state universities was 1622336 in academic years 2014-2015 (Council of Higher Education, 2015). The adequate sample size was calculated as 9547 when the confidence level was taken as $1.00 \%$ and the confidence interval was taken as $95.00 \%$. The number of students from each university was determined based on the ratio to the population. During sample selection, simple random sampling and cluster sampling methods were used. In selecting faculties, a random number table was used. In order to eliminate the travel difficulties that can be caused by simple random sampling, faculties located in the central campuses were selected through cluster sampling method (Krathwohl, 1993). When collecting data, gender and grade distribution were taken into consideration. The socio-demographic information about the study sample is presented in Table 1 .

\section{DATA COLLECTION MEASUREMENTS}

\section{Attitudes Toward Infertility Scale}

The Attitudes Towards Infertility Scale (ATIS) developed by Siyez, Baran, Esen, Kağnıcı, and Siyez (2018) to measure university students' attitudes towards infertility has 12 items. Of the 12,8 are negative and 4 are positive items. The ATIS is a five-point scale ranging from 1 (totally agree) to 5 (totally disagree). Higher scores obtained on the scale indicate positive attitudes towards infertility.

Reliability and validity studies of ATIS were conducted with two different study groups. To investigate the validity of the ATIS, content validity was analyzed in the first study group. Content validity of ATIS was examined by exploratory factor analysis (EFA). The results of EFA showed that the scale had a one-factor structure with 12 items that explained $45.33 \%$ of the variance. For the first study group, Cronbach's $\alpha$ reliability coefficient was found to be .85 while item-total correlations ranged between .46 and .58. Confirmatory factor analysis (CFA) was used to test the factor structure of the ATIS in the second study group. Results of CFA supported one factor construct $\left(\chi^{2}=136.17, d f=54\right)$. In the second study group, Cronbach's $\alpha$ reliability coefficient for the ATIS was found to be .83. In this study, Cronbach's $\alpha$ internal consistency coefficient for the scale was .81 .

\section{Table 1}

Socio-demographic information about sample

\begin{tabular}{|c|c|c|}
\hline Demographic variables & $f$ & $\%$ \\
\hline \multicolumn{3}{|l|}{ Gender } \\
\hline Female & 5002 & 51.60 \\
\hline Male & 4691 & 48.40 \\
\hline \multicolumn{3}{|l|}{ Grade level } \\
\hline Class 1 & 2336 & 24.10 \\
\hline Class 2 & 2679 & 27.64 \\
\hline Class 3 & 2841 & 29.31 \\
\hline Class 4 and upper & 1736 & 17.91 \\
\hline Undefined & 101 & 1.04 \\
\hline \multicolumn{3}{|l|}{ Mother education level } \\
\hline Non-literate & 715 & 7.38 \\
\hline Literate & 632 & 6.52 \\
\hline Primary school & 3595 & 37.09 \\
\hline Secondary school & 1450 & 14.96 \\
\hline High school & 2011 & 20.75 \\
\hline University & 1261 & 13.01 \\
\hline \multicolumn{3}{|l|}{ Father education level } \\
\hline None literate & 99 & 1.02 \\
\hline Literate & 295 & 3.04 \\
\hline Primary school & 2494 & 25.73 \\
\hline Secondary school & 1608 & 16.59 \\
\hline High school & 2604 & 26.87 \\
\hline University & 2578 & 26.60 \\
\hline
\end{tabular}

University students' attitudes towards infertility 


\section{Personal information form}

In the personal information form developed by researchers, there were questions about socio-demographic variables (gender, age, receiving sexual health education, having a sexual relationship, having infertile individuals in the social network, having plans about having a child) and risky behaviors (smoking cigarettes, drinking alcohol and caffeine excessively, having low or high body mass index).

Diğdem Müge Siyez,

Seçil Seymenler, Yelda Kağnıcı,

Erol Esen,

Ender Siyez, Bahar Baran

\section{DATA COLLECTION PROCESS}

Ethical board approval was obtained from Dokuz Eylul University Institute of Education Sciences Ethics Committee before collecting data. In addition, application permission was taken from all 21 universities. ATIS was administered to students in their classes by researchers. Before the administration of the scale, participants were informed about the aim of the study and informed consent was provided. It took approximately 30-35 minutes to complete the measures. A total of 10221 data were collected during the data collection process. However, it was decided not to use the data of students who left more than $10.00 \%$ of the scale items empty before starting the analysis of the data. For this reason, after the 528 missing data were extracted from the analysis, the sample of the study consisted of 9693 undergraduate students.

\section{DATA ANALYSIS}

Prior to the analysis, assumptions of parametric tests were examined. The mean score and median of ATIS were found to be the same (3.83), the mode was slightly smaller than the mean and median (3.67), and the skewness and kurtosis values of the variables were between +1 and -1 . Based on these values and sample size, it was decided to use parametric tests. In order to examine university students' attitudes towards infertility in terms of socio-demographic variables and risky behaviors, the $t$-test and one-way ANOVA were conducted. The program SPSS 23.0 was used in the analysis of the data and the significance value was accepted as $p<.05$.

\section{RESULTS}

\section{INVESTIGATING ATTITUDES TOWARDS INFERTILITY}

In order to examine university students' attitudes towards infertility, frequencies of results were examined. The findings are presented in Figure 1.
As seen in Figure 1, 26.99\% of the university students ( $n=2615)$ agreed that the lives of couples without a child are incomplete, indicating that they had a negative attitude towards infertility, and $33.89 \%$ $(n=3285)$ were undecided about having a relationship with an infertile individual, indicating that the attitudes have not dissociated clearly. $37.62 \%$ of students $(n=3646)$ mentioned that being infertile is not a reason for a partner to leave a woman; $70.05 \%$ $(n=6790)$ did not think that women who do not have a child are faulty and $61.70 \%(n=5981)$ did not think that men who do not have a child are faulty, indicating they had a positive attitude towards infertility. $38.19 \%$ of students $(n=3702)$ were undecided whether to share the information if they were infertile. Of the participants, $49.00 \%(n=4750)$ mentioned that they would not marry again if their partner was infertile.

\section{ATIS SCORES IN TERMS \\ OF SOCIO-DEMOGRAPHIC VARIABLES AND RISKY BEHAVIORS}

In order to examine university students' attitudes towards infertility in terms of socio-demographic variables and risky behaviors (gender, receiving sexual health education, having a sexual relationship, having infertile individuals in the social network, having plans about having a child, cigarette smoking) $t$-tests were conducted. The mean scores, standard deviations, and $t$-test results are presented in Table 2 .

As seen in Table 2, female students' mean scores were significantly higher than $(M=3.93, S D=0.57)$ male students $(M=3.72, S D=0.69), t(9365)=15.45$, $p<.001$. The mean scores of students who received sexual health education were significantly higher than $(M=3.89, S D=0.64)$ than scores of students who $\operatorname{did} \operatorname{not}(M=3.81, S D=0.64), t(8918)=5.58, p<.001$.

Sexual behaviors were examined in terms of having a sexual relationship. The mean scores of students who had a sexual relationship were significantly higher $(M=3.86, S D=0.71)$ than those of students who never had a sexual relationship $(M=3.82, S D=0.62)$, $t(9047)=2.24, p=.025$. The mean scores of students who had an infertile individual in the social network were significantly higher $(M=3.85, S D=0.62)$ than those of students who $\operatorname{did} \operatorname{not}(M=3.81, S D=0.65)$, $t(9286)=3.02, p=.003$. The mean scores of students who had a child plan were significantly higher than $(M=3.79, S D=0.62)$ those of students who did not $(M=4.18, S D=0.67), t(9322)=16.92, p<.001$.

Regarding smoking cigarettes, it was found that $45.38 \%$ of the participants $(n=4399)$ had never used cigarettes, $25.36 \%(n=2458)$ had tried a few times, $23.83 \%(n=2310)$ regularly smoked and $4.02 \%$ $(n=390)$ had quit smoking. In the analysis those who had never smoked cigarettes and those who regularly smoked were included. The mean scores of stu- 


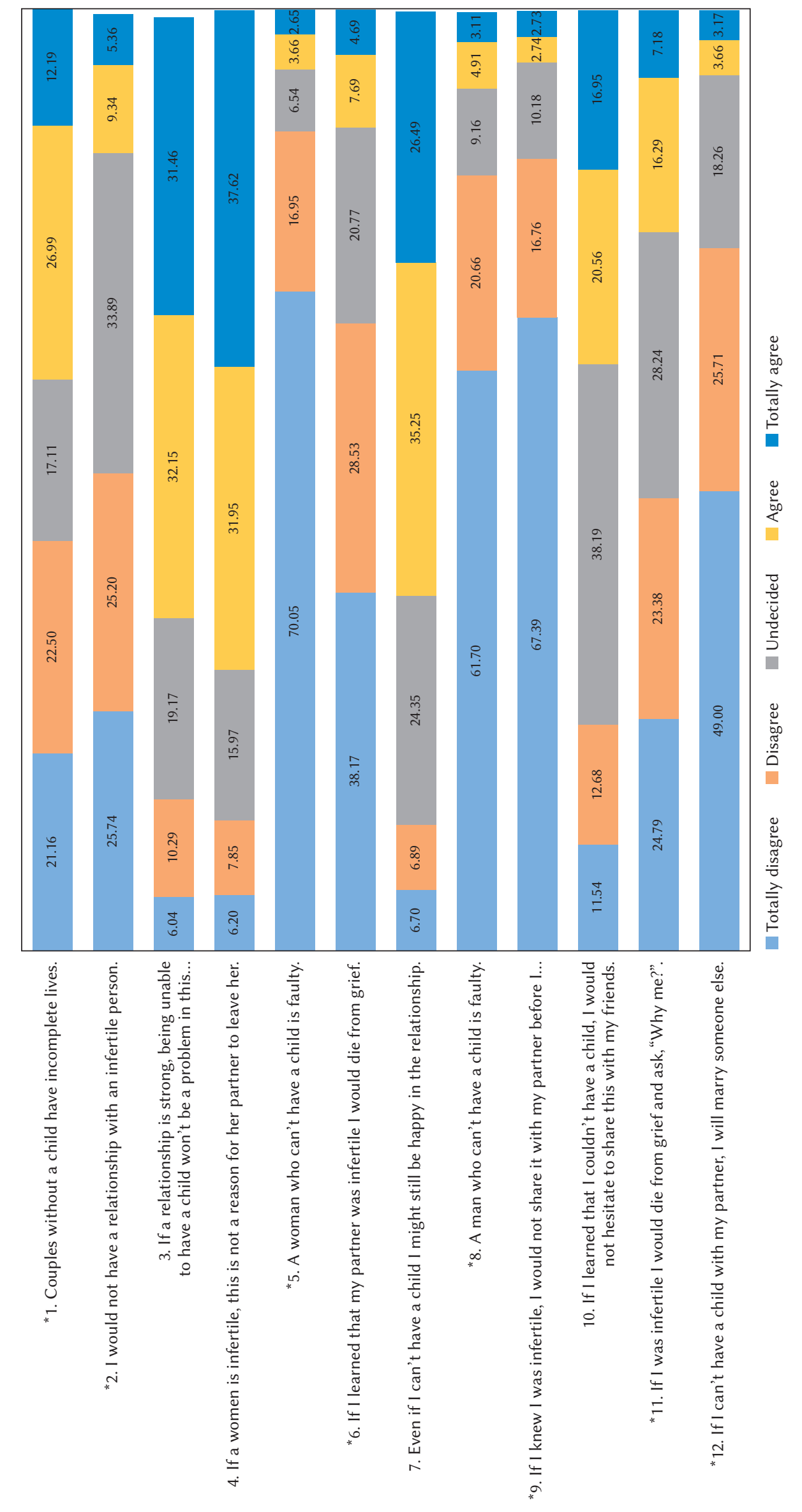

University students' attitudes towards infertility 
Table 2

Descriptive statistics and t-test results of university students' attitudes towards infertility in terms of demographic variables

\begin{tabular}{|c|c|c|c|c|c|}
\hline Variables & $n$ & M & $S D$ & $t$ & $p$ \\
\hline Gender & & & & 15.45 & $<.001$ \\
\hline Female & 4821 & 3.93 & 0.57 & & \\
\hline Male & 4546 & 3.72 & 0.69 & & \\
\hline Receiving sexual education & & & & 5.58 & $<.001$ \\
\hline Yes & 3025 & 3.89 & 0.64 & & \\
\hline No & 5895 & 3.81 & 0.64 & & \\
\hline Having a sexual relationship & & & & 2.24 & .025 \\
\hline Yes & 2122 & 3.86 & 0.71 & & \\
\hline No & 6927 & 3.82 & 0.62 & & \\
\hline $\begin{array}{l}\text { Existence of an infertile individual } \\
\text { in the social network }\end{array}$ & & & & 3.02 & .003 \\
\hline Yes & 3370 & 3.85 & 0.62 & & \\
\hline No & 5918 & 3.81 & 0.65 & & \\
\hline Plans about having a child & & & & 16.92 & $<.001$ \\
\hline Yes & 8431 & 3.79 & 0.62 & & \\
\hline No & 893 & 4.18 & 0.67 & & \\
\hline Cigarette usage & & & & 0.93 & .324 \\
\hline Non-smokers & 4248 & 3.83 & 0.61 & & \\
\hline Regular smokers & 2232 & 3.84 & 0.70 & & \\
\hline
\end{tabular}

dents who regularly smoked cigarettes were higher $(M=3.84, S D=0.70)$ than those of students who had never smoked $(M=3.83, S D=0.61)$. However, the mean difference between these two groups was not statistically significant; $t(6621)=0.93, p=.324$.

In order to examine whether university students' attitudes towards infertility differ in terms of age, caffeine usage frequency, alcohol usage frequency, and body mass index, one-way ANOVA was conducted. Results are presented in Table 3.

From Table 3, it can be seen that attitudes towards infertility mean scores did not significantly differ in terms of the age variable; $F(2,9250)=2.87, p=.057$. According to the results, the mean score of attitudes towards infertility significantly differed in terms of caffeine usage, $F(3,9341)=20.00, p<.001$. In order to find the source of difference, Dunnett's $C$ test was conducted. According to the results of Dunnett's C test mean ATIS scores of university students who drink more than 3 cups of coffee every day were significantly higher $(M=3.91, S D=0.70)$ than those of students who drink 2-3 cups in a week $(M=3.79$, $S D=0.63)$ and those who do not drink coffee $(M=3.77$, $S D=0.64)$. Also, mean ATIS scores of students who drink 1-2 cups of coffee every day were significantly higher $(M=3.88, S D=0.63)$ than scores of those who drink 2-3 cups of coffee in a week $(M=3.79, S D=0.63)$ and those who do not drink any $(M=3.77, S D=0.64)$.

According to the results, the mean score of attitudes towards infertility significantly differed in terms of alcohol usage; $F(3,9162)=45.64, p<.001$. In order to find the source of the difference, Dunnett's C test was conducted. According to the results of Dunnett's $\mathrm{C}$ test mean ATIS scores of university students who regularly drink alcohol $(M=3.98, S D=0.72)$ were significantly higher than the scores of those who do not drink $(M=3.77, S D=0.61)$ and those who had tried a few times $(M=3.84, S D=0.64)$. Mean ATIS scores of students who had tried alcohol a few times were significantly higher $(M=3.84, S D=0.64)$ than those of students who had never drunk alcohol $(M=3.77$, $S D=0.61)$.

In the analysis of body mass index, the data of participants who did not provide their height and weight information were deleted. Therefore, sample size decreased. According to data classification, those with body mass index in the range $0-18.40$ were thin, 18.40-24.90 normal, 25.00-29.90 overweight, and 30.00 
Table 3

Descriptive statistics and ANOVA results of university students' attitudes towards infertility in terms of demographic variables

\begin{tabular}{|c|c|c|c|c|c|}
\hline Variables & $n$ & $M$ & $S D$ & $F$ & $p$ \\
\hline Age & & & & 2.87 & .057 \\
\hline$<18$ & 829 & 3.84 & 0.60 & & \\
\hline $19-24$ & 8046 & 3.82 & 0.64 & & \\
\hline$>25$ & 378 & 3.90 & 0.66 & & \\
\hline Frequency of caffeine usage & & & & 20.00 & $<.001$ \\
\hline More than 3 cups every day & 832 & 3.91 & 0.70 & & \\
\hline 1-2 cups every day & 3224 & 3.88 & 0.63 & & \\
\hline $2-3$ cups in a week & 3965 & 3.79 & 0.63 & & \\
\hline None & 1324 & 3.77 & 0.64 & & \\
\hline Frequency of alcohol usage & & & & 45.64 & $<.001$ \\
\hline I don't drink & 4885 & 3.77 & 0.61 & & \\
\hline I have tried only a few times & 1267 & 3.84 & 0.64 & & \\
\hline I sometimes drink & 2415 & 3.93 & 0.66 & & \\
\hline I regularly drink & 599 & 3.98 & 0.72 & & \\
\hline Body mass index & & & & 8.17 & $<.001$ \\
\hline Thin & 875 & 3.92 & 0.58 & & \\
\hline Normal & 6399 & 3.82 & 0.63 & & \\
\hline Overweight & 1403 & 3.79 & 0.66 & & \\
\hline Obesity & 206 & 3.85 & 0.73 & & \\
\hline
\end{tabular}

or more obese. According to the results, attitudes towards infertility scores significantly differed in terms of body mass index; $F(3,8879)=8.17, p<.001$. In order to find the source of the difference, Dunnett's $C$ test was conducted. According to the results of Dunnett's $\mathrm{C}$ test mean ATIS scores of thin university students $(M=3.92, S D=0.58)$ were significantly higher than those of students with normal weight $(M=3.82$, $S D=0.63)$ and overweight $(M=3.79, S D=0.66)$.

\section{DISCUSSION}

In the present study we aimed to investigate university students' attitudes towards infertility according to some demographic variables and risky behaviors. The results of the study indicated that university students' attitudes towards infertility are relatively positive. This finding is considered as striking for Turkish culture where the words 'woman' and 'mother' are used simultaneously and the pressure to have a child is strongly felt (Şimşek, 2011). The participants' education level might be considered as a possible reason for this finding. According to a comprehensive study conducted in Turkey, a significant difference was found in terms of education level regarding the consideration of being unable to have a child as one of the reasons for divorce. According to the results, $10.50 \%$ of illiterates and $5.70 \%$ of graduates of university and graduate programs mentioned male infertility as one of the reasons for divorce, and $18.10 \%$ of illiterates and $7.70 \%$ of graduates of university and graduate programs mentioned female infertility as one of the reasons for divorce (Turkish Statistical Institute, 2006).

One of the interesting findings of the study was participants' potential behaviors in case they were infertile. According to the findings, $5.47 \%$ of the participants indicated that they would not share this information with their partners and $24.22 \%$ with their social network. The social pressure and the unwillingness to share information about their private life (Şimşek, 2011) might be the reasons for these findings. The social pressure about infertility is not observed only in developing countries. According to a study conducted in Sweden, women and men perceive being unable to have a child and social pressure as the reasons for psychological stress (Hjelmstedt et al., 1999). On the other hand, most
University students' attitudes towards infertility 
Diğdem Müge

Siyez,

Seçil Seymenler, Yelda Kağnıcı,

Erol Esen,

Ender Siyez,

Bahar Baran of the participants indicated that they would share this information with their partners. However, it is necessary to keep in mind that when evaluating infertility, having a health problem and having assumptions about it might prove different. According to a study about interventions about infertility, infertile couples accepted alternative intervention techniques more than fertile couples except adopting a child (Halman, Abbey, \& Andrews, 1992).

According to another finding, $39.18 \%$ of the participants believed that couples living without a child are incomplete. Actually, this finding is not surprising because in Turkey marriage means having a child (Kılıç, Ejder Apay, \& Kızılkaya Beji, 2011). Actually, having a child has cultural, economic, psychological and social value in many cultures: economic value consists of economic benefits ensured by children and being an assurance to parents in senescence; psychological value consists of the happiness, closeness of a child and the belief that a child is the reason for a happy marriage; and social value consists of social acceptance of married couples gained when they have a child (Kağıtçıbaşı, 2010). While having child is considered as a privilege and a reason for dignity, being unable to have a child results in isolation and stigmatization in society. According to a study conducted in Turkey among unmarried, married, divorced and widowed individuals, $0.02 \%$ to $1.16 \%$ of individuals indicated that they did not want to have a child, while $51.95 \%$ to $77.79 \%$ of the participants mentioned that they wanted 2-3 children (Turkish Statistical Institute, 2016b).

When the items "A man who can't have a child is faulty" and "A woman who can't have a child is faulty" are compared, it is seen that the ratio of agreement on the item related to men was higher than the item related to women. This finding might be related to the gender roles. In societies where being a man is associated with being strong and powerful, a role defined as maintaining the ancestry, being unable to have a child means being unable to meet the expectations related to men. Also in societies where infertility is associated with being sexually impotent (Evans, 2014), men could be perceived as faulty.

When results regarding attitudes towards infertility are evaluated in terms of gender, male university students' attitudes towards infertility were found to be more negative than those of female students. Similarly, in Taşcı and Özkan's (2007) study, male students' attitudes were found more negative. According to results conducted in Turkey, in partner selection one of the most important criteria for a man is the woman's fertility (Bacanl, 2001). These results can be understood when the society's structure is taken into consideration. In patriarchal societies, for men having a child means being strong.

In terms of age, although ATIS scores of participants who are older than 25 were higher than the others, no significant difference was found. Since participants were in a similar developmental period, this finding seems understandable.

In terms of receiving sexual health education, ATIS scores of participants who received sexual health education were higher than the others. Sexual health education programs' goals for young adults can be summarized as developing self-values, understanding responsibilities, realizing, analyzing and evaluating sexual attitudes (Sexuality Information and Education Council of the United States [SIECUS] 1996). Therefore these kinds of programs have positive effects on students' attitudes.

Having someone infertile in the social network was a significant factor. Students who knew someone infertile in the social network had more positive attitudes towards infertility. It can be considered that these participants were more familiar with the treatment process and the problems faced by infertile individuals. Observing these processes might affect participants in developing more positive attitudes.

Plans about having a child were the other significant factor. Attitudes of participants who had no child plans were more positive than the others. According to social learning theory, there is a circular relationship between expectations and performance. High expectations increase performance and increased performance results in high expectations (Bandura, 1977). In this manner, individuals who have child plans in the future are engaged more in close relationships and have marriage plans. Having close relationships and getting married bring up expectations about having a child. Therefore, university students who have child plans might perceive infertility as a barrier to their expectations and might have more negative attitudes.

As the other finding, ATIS scores of participants who smoke cigarettes and drink alcohol and caffeine regularly, which are considered as risk factors for infertility (Bunting \& Boivin, 2007; Wyndham et al., 2012), were higher than the others. Generally, it is considered that knowledge about negative effects of using the unhealthy substance on health would prevent use of these substances. However, mainly this assumption belongs to individuals who do not use these substances. Moreover, individuals who use these substances might not always be realistic about the risks they take (Manstead, 1996). This case, referred to as unrealistic optimism, means that individuals have a tendency to think that negative outcomes might be experienced by others more than themselves. In other words, individuals may think that their risks are lower than others who are of the same age or condition (Weinstein \& Klein, 1996). Therefore, participants who use cigarettes, alcohol, and caffeine regularly might think that the risk of being infertile is lower than that of other individuals.

The last variable examined in the study was body mass index. According to the results, thin partici- 
pants' attitudes towards infertility were more positive than the others. Although in the literature there are many studies examining low (underweight) and high body mass index (overweight) as risk factors for infertility (Pasquali et al., 2007; Schmid et al., 2004), no study was found examining the relationship between body mass index and attitudes towards infertility. Being thin, which is reinforced by media, is associated with wellbeing (Brown, Mishra, Kenardy, \& Dobson, 2000). Therefore, the positive nature of being well might positively affect attitudes towards infertility. However, it is recommended to examine this variable in detail in further studies.

There are also some limitations in the present study. The first limitation is related to the self-report nature of the scale. The participants intentionally or unintentionally might distort the answers (Heppner, Wampold, \& Kivlighan Jr, 2008). In order to eliminate this limitation, the dataset with more than $10.00 \%$ of missing cases was not excluded. Even though there are a few limitations, since the data were collected from the participants all over the country, the findings can be generalized.

In the light of the findings, some suggestions are provided for further studies. Although university students' attitudes towards infertility were relatively positive, male students' attitudes are more negative than female students. Therefore, in the future, psycho-education programs about infertility including gender role issues can be developed, applied and evaluated. The data in the present study were collected by the Attitudes Towards Infertility Scale. In the further studies, qualitative data might be collected. For example, reasons for unwillingness to share the infertility knowledge with the social network could be investigated in detail.

This study was supported by The Scientific and Technological Research

Council of Turkey-TÜBİTAK [grant number 215K001].

\section{REFERENCES}

Abolfotouh, M. A., Alabdrabalnabi, A. A., Albacker, R. B., Al-Jughaiman, U. A., \& Hassan, S. N. (2013). Knowledge, attitude, and practices of infertility among Saudi couples. International Journal of General Medicine, 6, 563-573.

Bacanlı, H. (2001). Mate preferences. Türk Psikolojik Danışma ve Rehberlik Dergisi, 2, 7-16.

Bandura, A. (1977). Self-efficacy: Toward a unifying theory of behavioral change. Psychological Review, 84, 191-215.

Brown, W. J., Mishra, G., Kenardy, J., \& Dobson, A. (2000). Relationships between body mass index and well-being in young Australian women. International Journal of Obesity, 24, 1360-1368.
Bunting, T. L., \& Boivin, J. (2007). Decision-making about seeking medical advice in an internet sample of women trying to get pregnant. Human Reproduction, 22, 1662-1668.

Burns, L. H. (2005). Psychological changes in infertility patients. In A. Rosen \& J. Rosen (eds.), Frozen dreams: Psychodynamic dimensions of infertility and assisted reproduction (pp. 3-29). Hillsdale, NJ: The Analytic Press, Inc.

Council of Higher Education. (2015). Number of students, 2015. Retrieved from https://istatistik.yok. gov.tr.

Evans, J. (2014). 'They are called imperfect men': male infertility and sexual health in early modern England. Social History of Medicine, 29, 311-332.

Gerhard, R. S., Ritenour, C. W., Goodman, M., Vashi, D., \& Hsiao, W. (2014). Awareness of and attitudes towards infertility and its treatment: A cross-sectional survey of men in a United States primary care population. Asian Journal of Andrology, 16, 858-863.

Gibson, D. M. (2007). The relationship of infertility and death: Using the relational/cultural model of counseling in making meaning. The Humanist Psychologist, 35, 275-289.

Güngör, I., Rathfisch, G., Kızılkaya Beji, N., Yarar, M., \& Karamanoğlu, F. (2013). Risk-taking behaviours and beliefs about fertility in university students. Journal of Clinical Nursing, 22, 3418-3427.

Halman, L. J., Abbey, A., \& Andrews, F. M. (1992). Attitudes about infertility interventions among fertile and infertile couples. American Journal of Public Health, 82, 191-194.

Harris, D. L., \& Daniluk, J. C. (2010). The experience of spontaneous pregnancy loss in infertile women who have conceived with the assistance of medical intervention. Human Reproduction, 25, 714-720.

Heppner, P. P., Wampold, B. E., \& Kivlighan Jr, D. M. (2008). Research design in counseling. Pacific Grove, CA: Brooks/Cole.

Hjelmstedt, A., Andersson, L., Skoog-Svanberg, A., Bergh, T., Boivin, J., \& Collins, A. (1999). Gender differences in psychological reactions to infertility among couples seeking IVF- and ICSI-treatment. Acta Obstetricia et Gynecologica Scandinavica, 78, 42-49.

Kağıtçıbaşı, Ç. (2010). Benlik, aile ve insan gelişimi: Kültürel psikoloji [Self, family, and human development: Cultural psychology]. İstanbul: Koç Üniversitesi Yayınları.

Kılıç, M., Ejder Apay, S., \& Kızılkaya Beji, N. (2011). Infertility and culture. Florence Nightingale Hemşirelik Dergisi, 19, 109-115.

Krathwohl, D. (1993). Methods of educational and social science research: An integrated approach. New York: Longman/Addison Wesley Longman.

Lampman, C., \& Dowling-Guyer, S. (1995). Attitudes toward voluntary and involuntary childlessness. Basic and Applied Social Psychology, 17, 213-222.
University students' attitudes towards infertility 
Manstead, A. S. R. (1996). General frameworks. In G. R. Semin \& K. Fiedler (eds.), Applied social psychology (pp. 1-91). London: Sage Publications.

Meissner, C., Schippert, C., \& Von Versen-Höynck, F. (2016). Awareness, knowledge, and perceptions of infertility, fertility assessment, and assisted reproductive technologies in the era of oocyte freezing among female and male university students. Journal of Assisted Reproduction Genetics, 33, 719-729.

Diğdem Müge Siyez,

Seçil Seymenler, Yelda Kağnıcı,

Erol Esen,

Ender Siyez,

Bahar Baran

Pasquali, R., Patton, L., \& Gambineri, A. (2007). Obesity and infertility. Current Opinion Endocrinology, Diabetes and Obesity, 14, 482-487.

Peterson, B. D., Pirritano, M., Tucker, L., \& Lampic, C. (2012). Fertility awareness and parenting attitudes among American male and female Undergraduate University students. Human Reproduction, 27, 1375-1382.

Ramezanzadeh, F., Aghssa, M. M., Abedinia, N., Zayeri, F., Khanafshar, N., Shariat, M., \& Jafarbadi, M. (2004). A survey of relationship between anxiety, depression and duration of infertility. BMC Women's Health, 4, 9-18.

Schmid, J., Kirchengast, S., Vytiska-Binstorfer, E., \& Huber, J. (2004). Infertility caused by PCOS health-related quality of life among Austrian and Moslem immigrant women in Austria. Human Reproduction, 19, 2251-2257.

Sewall, G., \& Burns, L. H. (2006). Involuntary childlessness. In S. N. Covington \& L. H. Burns (eds.), Infertility counseling: A comprehensive handbook for clinicians (pp. 411-427). New York: Cambridge University Press.

Sexuality Information and Education Council of the United States (SIECUS). (1996). Guidelines for comprehensive sexuality education (vol. 2). New York: SIECUS.

Siyez, D. M., Baran, B., Esen, E., Kağnıcı, Y. D., \& Siyez, E. (2018). Üniversite Ögrrencilerinin Infertiliteye Ilişkin Bilgi ve Tutumlarının Incelenmesi ve Infertiliteyi Ónleme Psiko-Eğitim Programı ile Çevrim içi Eğitim Programının Geliştirilerek Etkililiğinin Değerlendirilmesi [Examining university students' infertility knowledge and attitudes towards infertility and developing and evaluating infertility prevention psyho-education program and online education program]. TUBITAK 215K001 Project Research Report.

Slade, P., O’Neill, C., Simpson, A. J., \& Lashen, H. (2007). The relationship between perceived stigma, disclosure patterns, support and distress in new attendees at an infertility clinic. Human Reproduction, 22, 2309-2317.

Sørensen, N. O., Marcussen, S., Backhausen, M. G., Juhl, M., Schmidt, L., Tydén, T., \& Hegaard, H. K. (2016). Fertility awareness and attitudes towards parenthood among Danish University college students. Reproductive Health, 13, 146.
Şimşek, H. (2011). Effects of gender inequalities on women's reproductive health: The case of Turkey. Dokuz Eylül Üniversitesi Tıp Fakültesi Dergisi, 25, 119-126.

Taşcı, K. D., \& Özkan, S. (2007). University school for health sciences students' opinions about infertility. Turk Silahlı Kuvvetleri Koruyucu Hekim Bülteni, 6, 187-192.

Trent, M., Millstein, S. G., \& Ellen, J. M. (2006). Gender-based differences in fertility beliefs and knowledge among adolescents from high sexually transmitted disease-prevalence communities. Journal of Adolescent Health, 38, 282-287.

Turkish Statistical Institute. (2006). Aile Yapısı Araştırması [Family structure survey]. Retrieved from https://biruni.tuik.gov.tr/aileyapidagitimapp/aileyapi.zul.

Turkish Statistical Institute. (2016a). Istatistiklerle Gençlik [Youth in statistics]. Retrieved from http://www.tuik.gov.tr/PreHaberBultenleri. do? id=24648.

Turkish Statistical Institute. (2016b). Aile YapısI Araştırması [Family structure survey]. Retrieved from http://www.tuik.gov.tr/PreHaberBultenleri. do? id=21869.

Van den Broeck, U., Emery, M., Wischmann, T., \& Thorn, P. (2010). Counselling in infertility: Individual, couple and group interventions. Patient Education and Counseling, 81, 422-428.

Weinstein, N. D., \& Klein, W. M. (1996). Unrealistic optimism: Present and future. Journal of Social Clinical Psychology, 15, 1-8.

Wyndham, N., Marin Figueira, P. G., \& Patrizio, P. (2012). A persistent misperception: assisted reproductive technology can reverse the "aged biological clock”. Fertility and Sterility, 97, 1044-1047.

Yazdani, F., Kazemi, A., \& Ureizi-Samani, H. R. (2016). Studying the relationship between the attitude to infertility and coping strategies in couples undergoing assisted reproductive treatments. Journal of Reproduction Infertility, 17, 56-60.

Zegers-Hochschild, F., Adamson, D. G., Dyer, S., Racowsky, C., de Mouzon, J., Sokol, R., Rienzi, L., Sunde, A., Schmidt, L., Cooke, I. D., Simpson, J. L., \& van der Poel, S. (2017). The international glossary on infertility and fertility care. Human Reproduction, 32, 1786-1801. 